\title{
UPPER CAMBRIAN BIOSTRATIGRAPHY OF ESTONIA
}

\author{
Kaisa MENS, a Viive VIIRA, a Ivo PAALITS, ${ }^{\text {a }}$ and Ivar PUURA a
}

a Eesti Teaduste Akadeemia Geoloogia Instituut (Institute of Geology, Estonian Academy of Sciences), Estonia pst. 7, EE-0100 Tallinn, Eesti (Estonia)

b Tartu Ulikooli Geoloogia Instituut (Institute of Geology, Tartu University), Vanemuise 46, EE-2400 Tartu, Eesti (Estonia)

Present address: Institut für Geologie und Paläontologie, Technische Universität Berlin (Technical University of Berlin, Institute of Geology and Paleontology), Ackerstraße 79-76, Sekr. ACK 14, Berlin 13355, Deutschland (Germany)

Presented by D. Kaljo

Received April 2, 1993; accepted May 28, 1993

Abstract. In Estonia the Upper Cambrian is represented by siliciclastic rocks, mainly quartzose sand- and siltstones containing thin interlayers of greenish-grey clays in the lower and dark kerogenous argillites in the upper part of the section. The Upper Cambrian of Estonia is subdivided into four formations: Petseri, Ulgase, Tsitre, and Kallavere.

The biostratigraphic subdivision is based on three fossil groups-acritarchs, conodonts, and lingulates. Five acritarch-, four conodont-, and at least three lingulate-based biostratigraphic units are distinguished, which may be used in the Upper Cambrian stratigraphic scale of Estonia. Subdivision of the lower part of the section is more reliable on acritarchs and that of the upper part, on conodonts.

Using the succession of acritarchs and conodonts the Petseri and Ulgase formations are approximately correlated with the Olenus Zone and the latter also with the Parabolina spinulosa Zone (lower part). The Tsitre Formation (lower part) corresponds to the $P$. spinulosa (upper part) and Leptoplastus zones, its uppermost part to the Peltura scarabaeoides Zone and the lower part of the Kallavere Formation can be referred to Acerocare Zone.

Key words: acritarchs, conodonts, lingulates, Upper Cambrian, Estonia.

\section{INTRODUCTION}

In the framework of biostratigraphic studies of the Cambrian-Ordovician boundary beds in Estonia and neighbouring areas, a number of key sections have been described in detail during the past 10 years with the documentation of the distribution of acritarchs, conodonts, and lingulate brachiopods. Conodont zonation has also contributed to detailed biostratigraphic correlation of the Upper Cambrian deposits exposed in the outcrops along the Baltic-Ladoga clint (Kaljo et al., 1986; Попов et al., 1989). Alongside conodonts, lingulate brachiopods have proved to be useful for basinwide correlations, particularly between Estonian and Swedish sections (Puura \& Holmer, 1993). Acritarchs, which occur only in thin argillaceous interbeds of the sandstone sequence, serve as a basis for a detailed biostratigraphic subdivision of sections and for correlation with distant sequences worldwide (Волкова, 1990; Paalits, 1992a, 1992b).

Only part of the results of this research has been published, mostly as detailed descriptions of separate key sections (е. g. Хейнсалу et al., 1987, 1991; Kaljo et al., 1988; Mens et al., 1989). 
The purpose of the present paper is to document the co-occurrence of acritarchs, conodonts, and lingulates in Estonian Upper Cambrian sections and to discuss the relationships of their biounits. A tentative correlation of acritarch, conodont, and lingulate biounits with Scandinavian trilobite zones is presented.

\section{GEOLOGICAL SETTING}

In the present paper the Upper Cambrian is considered in its traditional extent for the East European Platform, i. e. from the base of the Agnostus pisiformis Zone to the top of the Acerocare Zone. As trilobites are lacking in Estonia and Cordylodus proavus is documented in the Nærsnes section, Norway, together with trilobites of the Acerocare Zone (Bruton et al., 1988), we have included also the C. proavus Zone level into our discussion.

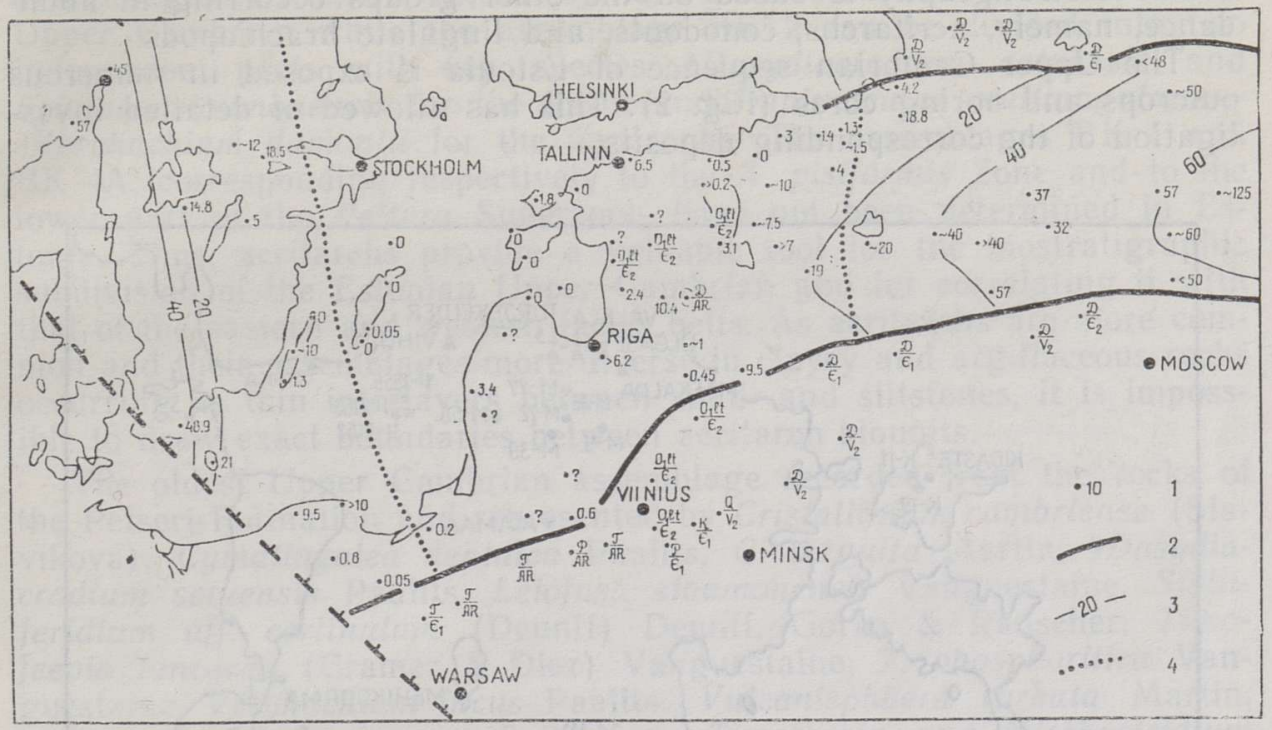

Fig. 1. The distribution, thickness, and facies of the Upper Cambrian in the northwestern part of the East European Platform.

1 - thickness of the corresponding deposits (up to the base of the Cordylodus succession); the question mark shows an undetermined Cambrian or Ordovician age of deposits; 2 - recent erosional boundary of the Upper Cambrian; 3 - isopachytes; 4 - boundary of a facies belt.

The Upper Cambrian rocks, which have been preserved from postCambrian erosion, are widely distributed in the north-western part of the East European Platform ranging as a sublatitudinal zone from the Oslo graben to the Moscow syneclise (Fig. 1). They are exposed along the Baltic-Ladoga clint area and in the river valleys intersecting it, occurring in the form of isolated patches also in the Oslo graben, South and Central Sweden, and are often allochthonously lying near the northwestern margin of the Platform. In the rest of the territory, the Upper Cambrian rocks are lying at a depth from a few metres (e.g. northern Estonia and southern Scandinavia) to two thousand metres (central part of the Moscow syneclise).

From the west to the east, the following lateral lithofacies sequences can be observed. In the west, approximately up to the Prabuty-ÖlandNärke line, alum shales are prevailing. Eastwards, there occurs a facies 
of sand-and siltstones, with rare thin interlayers of so-called Dictyonema shale, clay and sandstones with lenses of lingulate brachiopod valves and debris. East of the Ladoga-Porhov line, the Upper Cambrian is represented by siltstones and clays, more rarely by sandstones, while organic-rich rocks are absent (Fig. 1)

The sections of these three areas, tentatively distinguished as western, transitional, and eastern facies belts, differ not only in lithology and thickness, but also in stratigraphic completeness (see Mens et al., 1990) and paleontological evidences.

The Upper Cambrian biostratigraphy of the western facies belt is mainly based on trilobites and their zonation serves as a standard for platform correlation and a basis for interregional correlation (Westergård, 1922). From these sections of the transitional belts no trilobites have been found whereas the sections of the eastern facies belt have yielded only a few specimens. In the transitional belts the Upper Cambrian biostratigraphy is based on the other groups occurring in abundance, namely, acritarchs, conodonts, and lingulate brachiopods.

The Upper Cambrian sequence of Estonia is exposed in numerous outcrops and boring cores (Fig. 2). This has allowed of detailed investigation of the corresponding deposits.

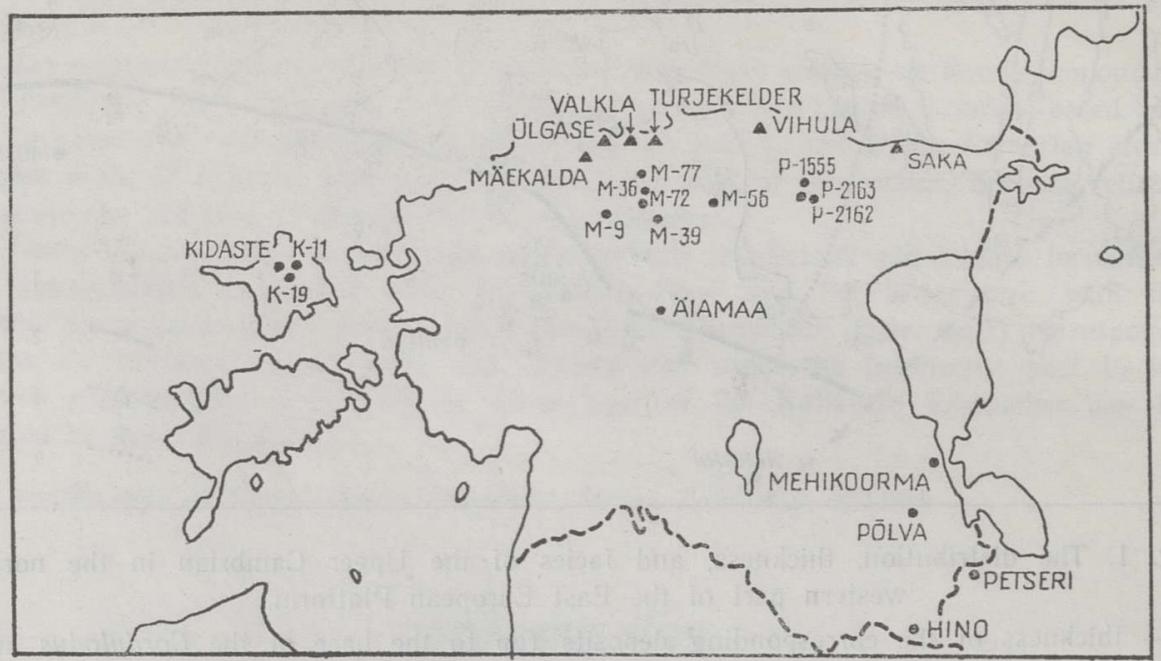

Fig. 2. Location of the main outcrops (triangles) and borings (solid circles) mentioned in the text.

In Estonia the strata considered as the Upper Cambrian are siliciclastic, dominated by silt- and sandstones less than $20 \mathrm{~m}$ in thickness (Fig. 1). Argillaceous rocks are limited, forming greenish-grey clayey interlayers within light-coloured coarse-grained deposits while in the uppermost part of the section they are often represented by their kerogenbearing variety, the Dictyonema shales.

The Upper Cambrian succession is very condensed and interrupted by several minor as well as major hiatuses. The presence of gaps is supported by petrographic evidences and by the absence of one or some biounits in the section.

The Upper Cambrian lies mainly on Lower Cambrian silt- and sandstones and only locally on Middle Cambrian rocks. It is overlain by Tremadocian siliciclastics, in places by younger Ordovician limestones.

According to the stratigraphic subdivision, the Upper Cambrian 
includes the Petseri, Ulgase, and Tsitre formations and a part of the Kallavere Formation. The Petseri Formation, known only in the subsurface, is distributed in south-eastern Estonia (see Волкова et al., 1981). The other three formations occur more widely in northern Estonia (Kaljo et al., 1986; Mens et al., 1990; etc.).

Acritarchs have been studied from the Tõnismägi, Mäekalda, Suhkrumägi, Ulgase, Valkla, Turjekelder, Vihula, and Saka outcrops and from the boring cores M-9, M-36, M-46, M-56, M-72, M-77, P-2162, Hino, Mehikoorma, Petseri, and Põlva (Fig. 2).

The taxonomic diversity and stratigraphic as well as relatively wide lateral distribution of acritarchs have enabled to establish the guide assemblages within the Upper Cambrian succession of the East European Platform including six acritarch assemblages (BK 1, BK 2, BK 3, ВК 4A, ВК 4Б, ВК 5) by Volkova (Волкова, 1990). Three similar assemblages (BK 3, BK 4Б, BK 5) have been established in the Estonian Upper Cambrian while the assemblage BK 2 can be divided into two independent parts with key species ?Dasydiacrodium setuensis and Leiofusa stoumonensis for the lower and Impluviculus multiangularis?Veryhachium dumontii for the upper one. The assemblages BK 1 and $\mathrm{BK} 4 \mathrm{~A}$, corresponding respectively to the $A$. pisiformis Zone and to the lower part of the Peltura Superzone, have not been determined in Estonia. Thus, acritarchs provide a valuable tool for the biostratigraphic subdivision of the Estonian Upper Cambrian and for correlating it with that of the eastern and western facies belts. As acritarchs are more common and their assemblages more diverse in clayey and argillaceous rocks occurring as thin interlayers between sand- and siltstones, it is impossible to draw exact boundaries between acritarch biounits.

The oldest Upper Cambrian assemblage recorded from the rocks of the Petseri Formation and represented by Cristallinium cambriense (Slavikova), Cymatiogalea dentalea Paalits, C. virgulta Martin, ?Dasydiacrodium setuensis Paalits, Leiofusa stoumonensis Vanguestaine, Stelliferidium aff. certinulum (Deunff) Deunf,, Gorka \& Rauscher, Timofeevia lancarae (Cramer \& Diez) Vanguestaine, T. phosphoritica Vanguestaine, Veryhachium incus Paalits, Vulcanisphaera turbata Martin, and species of the genera Poikilofusa, Timofeevia, and Micrhystridium (Волкова, 1990; Paalits, 1992b), has not been found anywhere else in Estonia.

Based on the occurrence of the genera Stelliferidium, Cymatiogalea, Leiofusa, and Veryhachium, which appeared in the Olenus time (Potter, 1974; Downie, 1984), and the absence of the Impluviculus species, the deposits yielding this acritarch assemblage are considered as a stratigraphic equivalent of the lower and/or middle parts of the Olenus Zone.

The next acritarch assemblage is similar to the one described, but differs in the presence of the representatives of the genus Impluviculus and in the lack or restricted distribution of typical Middle Cambrian species (Волкова, 1982). In all the studied sections this assemblage occurs in the Ulgase Formation. As the appearance of the genus Impluviculus has been correlated with the uppermost part of the Olenus Zone (Downie, 1984) and with the lowermost part of the $P$. spinulosa Zone (Martin \& Dean, 1988), we regard the Ulgase Formation tentatively as a stratigraphic equivalent of the uppermost Olenus and the lowermost Parabolina zones (Table).

The third Upper Cambrian assemblage, containing Trunculumarinum revinium (Vang.) Loeblich et Tappan, Dasydiacrodium caudatum Vanguestaine, D. obsenum Martin, Leiofusa stoumonensis Vanguestaine, Veryhachium dumontii Vanguestaine, Cymatiogalea wironia Paalits, $C$. 


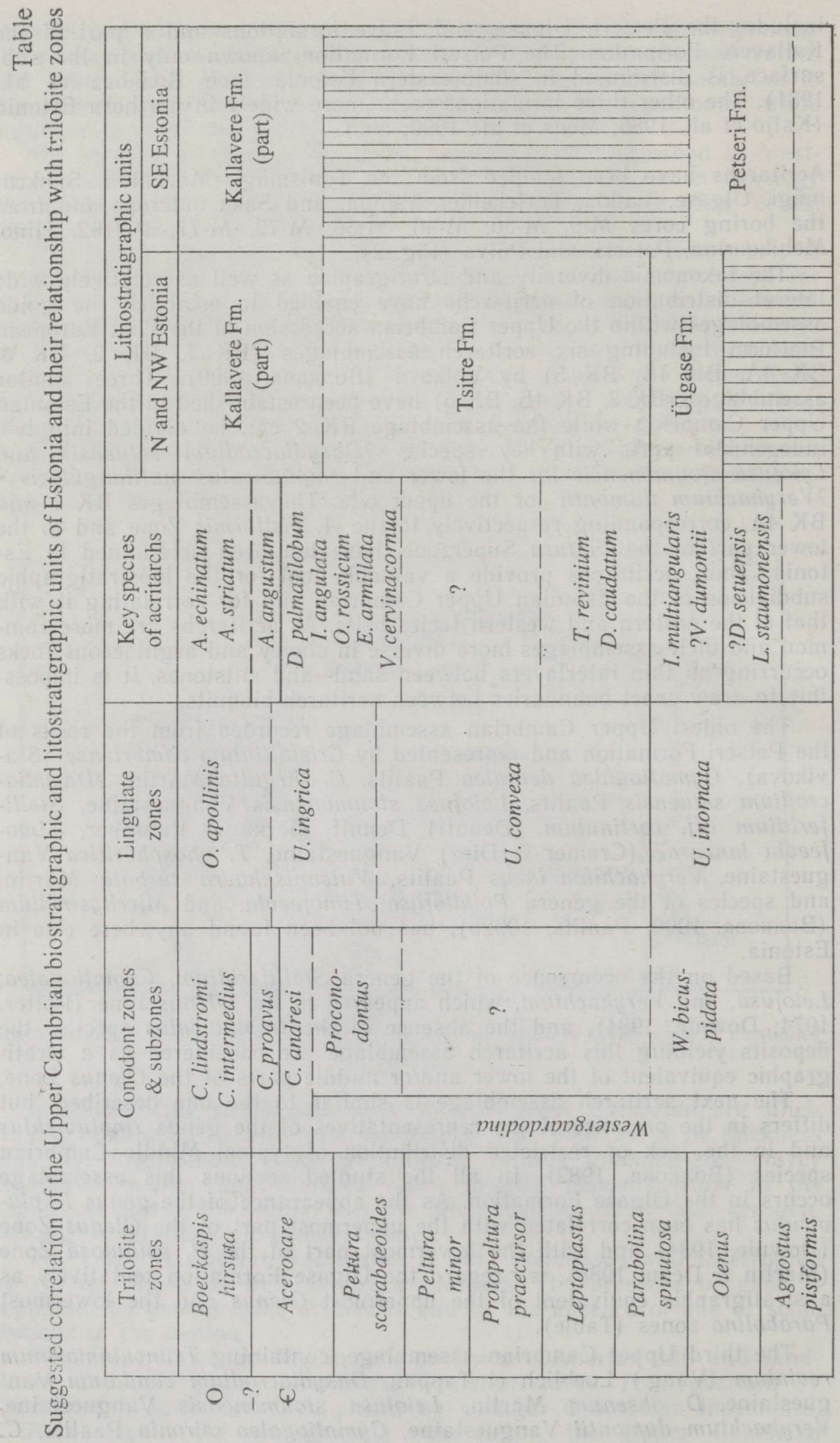


dentalea Paalits, C. aff. virgulta Martin, C. sp. sp., Goniosphaeridium aff, tuberatum (Downie) Wolf, G. aff. dentatum (Timofeev) Rauscher, G. sp. sp., Stelliferidium cortinulum (Deunff) Deunff, Gorka \& Rauscher, S. aff. pseudoornatum Pittau, Timofeevia phosphoritica Vanguestaine, T. estonica Volkova, Vulcanisphaera turbata Martin, V. sp., Actinodissus sp., Cristallinium sp., corresponds to the microflora $A_{4}$, i.e. $T$. reviniumD. caudatum assemblage sensu Martin \& Dean (1988) and to assemblage ВК-3 sensu Volkova (Волкова, 1990). In northern Estonia, this assemblage occurs in the lowermost part of the Tsitre Formation found only in boring cores $M-9$, depth 134.5-140.6 m; M-46, depth 38.7-40.5 m; M-72, depth 112.8-119.6 m (Paalits, 1992a.; Волкова, 1990). The tentative correlation of this assemblage with the trilobite zones is based on Trunculumarinum revinium and Dasydiacrodium caudatum known as the species with a limited stratigraphic range from the uppermost $P$. spinulosa Zone through the whole Leptoplastus Zone (Table).

The next acritarch assemblage, showing high taxonomic diversity and variation in different sections, contains a significant amount of diacroids and maybe endemic forms. On the East European Platform this assemblage was first described from the upper part of the Ladoga Formation, St. Petersburg area (Волкова \& Голуб, 1985), and is referred to as ВK-4Б (Волкова, 1990). It is characterized by the prevalence of Acanthodiacrodium timofeevii Volkova et Golub, Ladogiella rotundiformis Volkova et Golub, Calyziella izhoriensis Volkova et Golub, Izhoria angulata Volkova et Golub, Nellia longiscula Volkova et Golub, Schizodiacrodium fibrosum Volkova et Golub, Dasydiacrodium palmatilobum Timofeev, Elenia armillata (Vand.) Volkova, in some samples by Ooidium timofeevii Loeblich and O. rossicum Timofeev. In Estonia this acritarch assemblage is found from the upper part of the Tsitre Formation of the Valkla, Turjekelder, and Saka outcrops and from the boring cores P-2162, depth 115.4-115.6 m, and M-56, depth 138.6-147.4 m, together with the conodonts of the Proconodontus Subzone. These acritarchs have also been found in the Cordylodus andresi Zone of the Vihula section (Волкова, 1990). A relatively similar assemblage together with the trilobites of the Peltura scarabaeoides Zone has been determined from the Degerhamn section of southern Öland (di Milia et al., 1989).

The youngest Upper Cambrian acritarch assemblage which, as the above one, contains a large number of diacroids (Волкова, 1989, 1990), can be distinguished by the appearance of Acanthodiacrodium angustum (Downie) Combaz and Dicrodiacrodium ramusculosum (Combaz) Volkova. It is found together with conodonts of the $C$. proavus Zone from the lower part of the Kallavere Formation of the Tõnismägi, Mäekalda, Suhkrumägi, and Vihula outcrops and from the boring core M-9, depth $131.1 \mathrm{~m}$.

Conodonts have been studied from a number of outcrops and boring cores embracing the Cambrian-Ordovician boundary beds. Late Cambrian conodonts have been found in the Mäekalda, Suhkrumägi, Ulgase, Valkla, Turjekelder, Vihula, Toolse, and Saka outcrops and from the Kidaste and M-9 boreholes (Fig. 2). The number of specimens is small, representing mostly the genera Phakelodus, Furnishina, Prooneotodus, and Westergaardodina. Eoconodonts (Proconodontus, Eoconodontus, and Cordylodus) have been found only in the uppermost Upper Cambrian.

Here we accept the conodont zonation proposed by Viira and Sergeyeva for the correlation of the Cambrian-Ordovician boundary beds along the Baltic-Ladoga clint area (see Боровко \& Сергеева, 1985; Kaljo et al., 1986). According to this zonation, the Upper Cambrian sequence is subdivided as follows, starting from below: the 

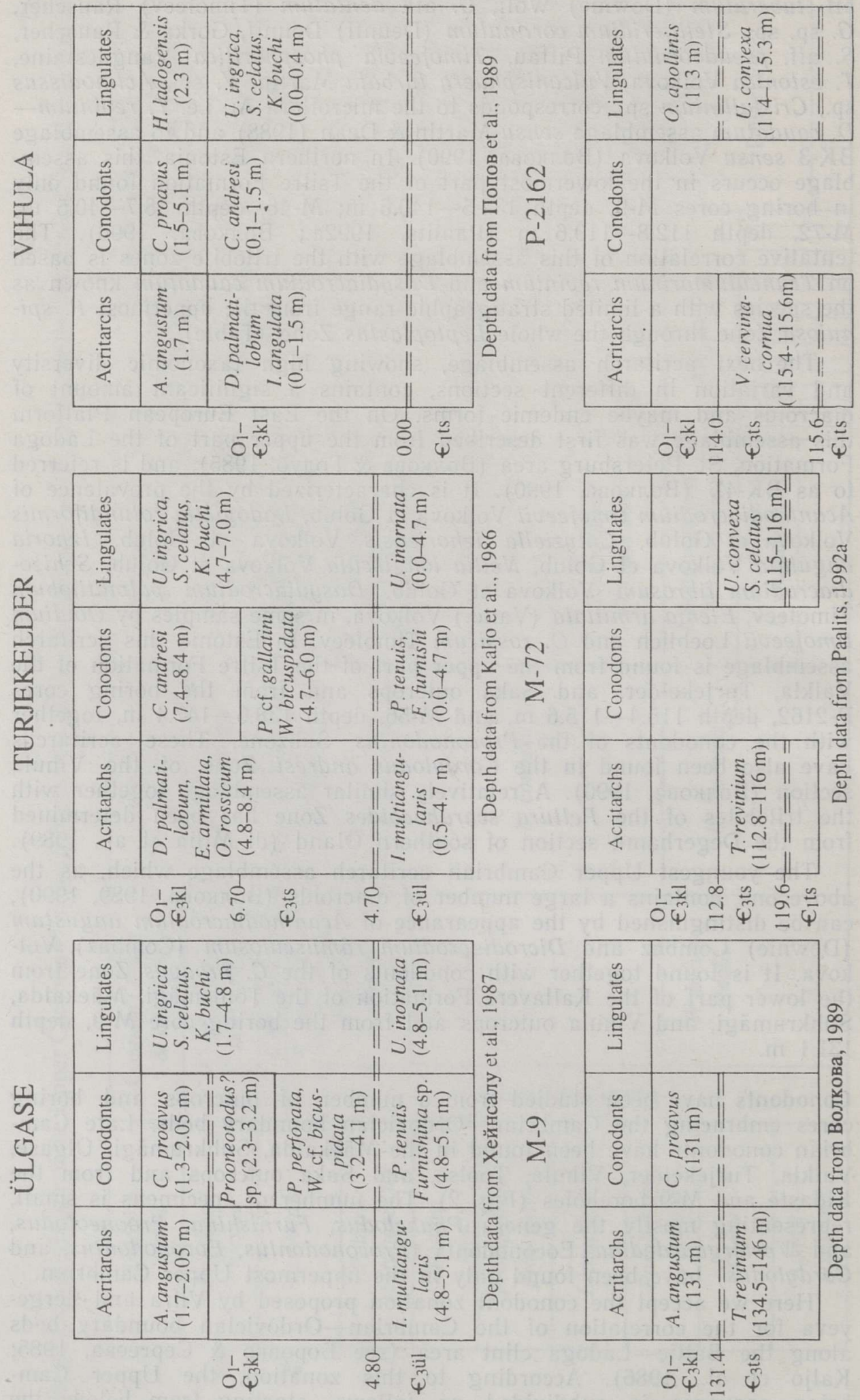
Westergaardodina Zone with W. bicuspidata, W. moessenbergensis, and Proconodontus subzones, and the Cordylodus andresi and C. proavus zones.

The Westergaardodina bicuspidata Subzone is distinguished by the species Phakelodus tenuis (Müller), Furnishina furnishi Müller, F. alata Szaniawski, and Prooneotodus terashimai (Nogami). The zonal species $W$. bicuspidata is very rare. The conodont assemblage of the W. bicuspidata Subzone has been found from the Ulgase Formation of the Mäekalda, Suhkrumägi, Ulgase, Jägala, Valkla, and Turjekelder outcrops and boring core M-9 (Боровко \& Сергеева, 1985; Хейнсалу et al., 1987; Kaljo et al., 1986; Mens et al., 1989). As provisionally correlated with the trilobite zonation, the W. bicuspidata Zone would correspond to the Agnostus pisiformis, Olenus, and the lowermost Parabolina spinulosa zones (Боровко \& Сергеева, 1985).

The Westergaardodina moessenbergensis Subzone has not yet been established in Estonia (Kaljo et al., 1986).

The Proconodontus Subzone is distinguished by the occurrence of Proconodontus primitivus (Müller), Prooneotodus cf. gallatini (Müller), and Problematoconites perforata Müller appearing in the eastern sections of the Leningrad Region already in the Westergaardodina moessenbergensis Subzone. This conodont assemblage has been found from the Tsitre and lowermost Kallavere formations of the Ulgase, Turjekelder, and Saka sections. The thickness of the rocks corresponding to this zone is up to $2 \mathrm{~m}$ (Kaljo et al., 1986; Хейнсалу et al.,1987). Proceeding from the co-occurrence of the above-mentioned conodonts with such acritarchs as Elenia armillata, Dacydiacrodium palmatilobum, and Ooidium rossicum (Fig. 3), the Proconodontus Subzone is tentatively correlated with the Peltura scarabaeoides Zone.

The Cordylodus andresi Zone represents the beginning of the Cordylodus succession in many sections along the Baltic-Ladoga clint (Kaljo et al., 1986; Viira et al., 1987). The conodont assemblage of this zone is established in the lower, up to $2 \mathrm{~m}$ thick part of the Kallavere Formation of the Ulgase, Valkla, Turjekelder, Toolse, and Vihula outcrops and Kidaste borehole on Hiiumaa Island. Besides the zonal species, the assemblage of the $C$. andresi Zone contains Eoconodontus notchpeakensis (Miller), Cordylodus viruanus Viira et Sergeyeva, and the long-ranging species of an earlier appearance Phakelodus tenuis, Furnishina furnishi, Westergaardodina bicuspidata, Prooneotodus cf. gallatini, and Muellerodus sp. Outside the transitional facies belt, $C$. andresi has been found from the Westergardia Subzone of the Acerocare Zone on the island of Oland (Andres, 1981) and together with Parabolina heres heres from the Zharnovez Region of northern Poland (Lendzion, pers. comm.).

The Cordylodus proavus Zone is established in numerous studied sections, mostly from the lower part of the Kallavere Formation. In addition to the index species Eoconodontus notchpeakensis, Cordylodus andresi, and long-ranging paraconodonts occur.

Recent studies of the Cambrian-Ordovician boundary interval in the Nærsnes section, Norway, have shown that the first Cordylodus proavus appeared already on the level of the Acerocare ecorne Subzone, i.e. in the uppermost subzone of the Acerocare Zone (Bruton et al., 1988). Taking this into account, deposits of the $C$. proavus Zone and its sup-

Fig. 3. Co-occurrence of the key species of acritarchs, conodonts, and lingulates in selected Upper Cambrian sections of Estonia.

Indexes of stratigraphic units: $\mathrm{O}_{1}-\epsilon_{3} \mathrm{kl}-$ Kallavere Formation, $\epsilon_{3}$ ts - Tsitre Formation, $\epsilon_{3} u ̈ l$ - Ulgase Formation. Double dashed line marks absence of one or some biounits. 
posed stratigraphic equivalents are included within the Upper Cambrian (Table).

Lingulate brachiopods are represented in the Upper Cambrian of Estonia by lingulids and acrotretids. Their stratigraphic distribution has been studied in a number of sections including Tõnismägi, Mäekalda, Suhkrumägi, Ulgase, Valkla, Turjekelder, Vihula, and Saka outcrops and the Kidaste, Aiamaa, M-9, M-72, M-77, P-2162 boring cores, where acritarchs or conodonts have often been studied (Fig. 2).

Following the brachiopod zonation suggested by Popov and Khazanovitch (Попов et al., 1989) and adopted by Puura \& Holmer (1993), the following four brachiopod zones can be distinguished, starting from below: the Ungula inornata Zone, the Ungula convexa Zone, the Ungula ingrica Zone, and the Obolus apollinis Zone. The first three zones belong to the Upper Cambrian, while the last one can belong partly to the Ordovician, depending on the position of the lower boundary of the Ordovician System.

The Ungula inornata Zone yields, besides the zonal species, Oepikites fragilis Popov \& Khazanovitch, Ceratreta tanneri (Metzger), and Angulotreta postapicalis Palmer. The lingulata assemblage of the Ungula inornata Zone has been found from the Ulgase Formation in the Tonismägi, Mäekalda, Suhkrumägi, Iru, Ulgase, Valkla, and Turjekelder outcrops and $M-9$ and $M-77$ boring cores.

The Ungula convexa Zone yielding besides the zonal species Oepikites triquetrus Popov \& Khazanovitch and Keyserlingia reversa (de Verneuil) was distinguished by Popov and Khazanovitch (Попов et al., 1989) only from the Leningrad Region and correlated with the lowermost Upper Ladoga Subformation. Recently, Ungula convexa has been found in the Tsitre Formation of Estonia from the Saka section and boring cores P-2162, depth 114-115.36 m; P-2163, depth 108.8-111.3 m; and M-72, depth $115-116 \mathrm{~m}$, in the last case together with Schmidtites celatus. Only Oepikites triquetrus has been determined from boring cores $M-39$, depth 165.2-168.7 m; M-77, depth $29.2 \mathrm{~m}$.

The distributional data from boring core M-72 (Fig. 3) are interesting because $U$. ingrica and $S$. celatus have been met together with an acritarch assemblage yielding Trunculumarinium revinium (Paalits, 1992a), which has a relatively narrow time span (Martin \& Dean, 1988). On the ground of these data the lower boundary of the $U$. convexa Zone is lowered (Table) in comparison with the primary one (Попов et al., 1989).

The Ungula ingrica Zone yielding $U$. ingrica (Eichwald), Schmidtites celatus (Volborth), Keyserlingia buchii (de Verneuil), and Oepikites obtusus (Mickwitz) corresponds to the uppermost part of the Tsitre Formation and the lowermost part of the Kallavere Formation of the Tõnismägi, Mäekalda, Suhkrumägi, Iru, Ulgase, Valkla, Turjekelder, Vihula, Aseri, and Saka outcrops and boring core $M-77$, depth $24.2-34.3$ $\mathrm{m}$. Its stratigraphic range is relatively clearly defined by conodont and acritarch co-occurrences.

The Obolus apollinis Zone with the lower boundary coinciding with that of the Cordylodus proavus conodont Zone in the Leningrad Region, yields the species Obolus apollinis (Eichwald) and Helmersenia ladogensis (Jeremejew). These species are widely distributed in the Tosno Formation of the Leningrad Region, but rather rare in Estonia, being known from the boring cores of Kidaste, K-11, and K-19 on Hiiumaa Island and P-1555 and P-2162 of the Rakvere phosphate deposits area. Helmersenia ladogensis has been found from K-11 core on Hiiumaa Island and reported from the Vihula section (Попов \& Хазанович, 
1989). Very often the finds of $O$. apollinis and/or $H$. ladogensis are related to the occurrences of Cordylodus proavus and Acanthodiacrodium angustum.

\section{DISCUSSION AND CONCLUSIONS}

The studied three groups of fossils-acritarchs, conodonts, and lingulate brachiopods-complement one another in respect of biostratigraphic correlation. Therefore, the documentation of their co-occurrences in a series of Estonian Upper Cambrian sections (Fig. 3) gives useful information both for short- and long-distance biostratigraphic correlation.

The oldest Upper Cambrian lithostratigraphic unit of Estonia, the Petseri Formation, is at present characterized only by acritarchs including Leiofusa stoumonensis Vanguestaine and ?Dasydiacrodium setuensis Paalits (Table), which show early late Cambrian age.

The next lithostratigraphic unit, the Ulgase Formation, contains representatives of all the groups studied. Of the highest correlative value are Impluviculus multiangularis, Westergaardina bicuspidata, and Ungula inornata, indicating the deposition of the corresponding sediments during the first half of the late Cambrian.

The lower part of the Tsitre Formation is characterized by an association of lingulates and acritarchs, the acritarch Trunculumarinum revinium having a short stratigraphic range. Conodonts have not been found as yet from this part of the sequence, which is revealed only in a few boring cores. The upper part of the Tsitre Formation, however, yields acritarchs, conodonts, and lingulates, including also conodonts of the Proconodontus Subzone (Fig. 3, Turjekelder Section).

The upper stratigraphic boundary of the acritarch assemblage containing Dasydiacrodium palmatilobum, Ishoria angulata, etc. coincides with that of the Cordylodus andresi Zone.

The most debatable is the position of the boundary between the Ungula ingrica and Obolus apollinis zones in relation to the lower boundary of the Cordylodus proavus Zone. The acritarch assemblage with Acanthodiacrodium angustum appears at the base of the Cordylodus proavus Zone. In northern Estonian sequences $C$. proavus and $A$. angustum co-occur with Ungula ingrica. O. apollinis, which is distributed in a sublatitudinal belt extending from the Leningrad Region to the Rakvere phosphate deposit area and Hiiumaa Island, is always known to appear above the base of the $C$. proavus Zone. Defining the boundary between $U$. ingrica and $O$. apollinis zones by the first appearance of $O$. apollinis, we leave the question of its detailed correlation with the lower boundary of the $C$. proavus Zone open. Our provisional correlation provided in the Table shows the lower boundary of the $O$. apollinis Zone slightly below the top of the Acerocare Zone.

The tentative correlation of the Estonian Upper Cambrian biounits with Scandinavian trilobite zones is mostly based on acritarch correlation and only within the Acerocare Zone on conodonts. However, the direct correlation is possible only partly because of the lack of data on the distribution of acritarchs of the Agnostus pisiformis, Leptoplastus, Protopeltura praecursor, Peltura minor, and Acerocare zones in Scandinavia.

In all probability, stratigraphic analogues of the Olenus, Parabolina spinulosa, and Peltura scarabaeoides zones can be distinguished in Estonia. The Cordylodus andresi and C. proavus zones, respectively, correspond to the Westergardia and A. ecorne subzones of the Acerocare Zone. 
The sandy lower part of the Petseri Formation has not yielded fossils. As the overlying clays in the middle part of this formation contain acritarchs of the Olenus Zone, the correlation of those barren sandstones with the Agnostus pisiformis Zone has been suggested (Mens et al., 1990).

The acritarch assemblage with Trunculumarinum revinium and Dasydiacrodium caudatum from the lower part of the Tsitre Formation, in addition to the upper part of the $P$. spinulosa Zone, is tentatively correlated with the Leptoplastus Zone.

\section{ACKNOWLEDGEMENTS}

We thank Anne Noor for linguistic help. Technical support by Kaie Ronk and Urve Pohl is also gratefully acknowledged.

\section{REFERENCES}

Andres, D. 1981. Beziehungen zwischen kambrischen Conodonten und Eoconodonten. Berliner Geowiss. Abh. A., 32, 19-31.

Bruton, D. L., Koch, L., Repetski, J. E. 1988. The Nærsnes section, Oslo Region, Norway: Trilobite, graptolite and conodont fossils reviewed. - Geol. Mag., 125, 4, $451-455$.

di Milia, A., Ribecai, C., Tongiorgi, M. 1989. Late Cambrian acritarchs from the Peltura scarabaeoides trilobite zone at Degerhamn (Oland, Sweden). - Palaeontographia Italica, LXXVI, $1-55$.

Downie, C. 1984. Acritarchs in British Stratigraphy. Geol. Soc. London. Special Report, 17, 261.

Kaljo, D., Borovko, N., Heinsalu, H., Khazanovitch, K., Mens, K., Popov, L., Sergeyeva, S., Sobolevskaya, R., Viira, V. 1986. The Cambrian-Ordovician boundary in the Baltic-Ladoga clint area (North Estonia and Leningrad Region, USSR). - Proc. Acad. Sci. ESSR. Geol., 35, 3, 97-108.

Kaljo, D., Heinsalu, H., Mens, K., Puura, I., Viira, V. 1988. Cambrian-Ordovician boundary beds at Tõnismägi, Tallinn, North Estonia. - Geol. Mag., 125, 4, 457-463.

Martin, F., Dean, W. T. 1988. Middle and Upper Cambrian acritarch and trilobite zonation at Manuels River and Random Island, eastern Newfoundland. - Bull. Geol. Surv. Canada, 381, 1-91.

Mens, K., Bergström, J., Lendzion, K. 1990. The Cambrian System of the East European Platform (Correlation chart and explanatory notes). - Intern. Union of Geol. Sciences, 25, 78.

Mens, K., Viira, V., Paalits, I., Puura, I. 1989. Cambrian-Ordovician boundary beds at Mäekalda (Tallinn, North Estonia). - Proc. Estonian Acad. Sci. Geol., 38, 3, 101-111.

Paalits, I. 1992a, Upper Cambrian acritarchs from boring core M-72 of North Estonia. - Proc. Estonian Acad. Sci. Geol., 41, 1, 29-37.

Paalits, I. 1992b. Upper Cambrian acritarchs from the Petseri Formation (East European Platform). - Tartu Ulikooli Toimetised, 956. Töid geoloogia alalt, XIII, 44-55.

Potter, T. L. 1974. British Cambrian acritarchs-a preliminary account. - Rev. Palaeobot. Palynol. (Special issue on acritarchs), 18, 61, 62 .

Puura, I., Holmer, L. E. 1993. Lingulate brachiopods from the Cambrian-Ordovician boundary beds in Sweden,-Geologiska Föreningens i Stockholm Förhandlingar 115 , pt. 3, 215-237.

Viira, V., Sergeyeva, S., Popov, L. 1987. Earliest representatives of the genus Cordylodus (Conodonta) from Cambro-Ordovician boundary beds of North Estonia and Leningrad Region. - Proc. Acad. Sci. ESSR. Geol., 36, 4, 145-153. 
Westergård, A. H. 1922. Sveriges Olenidskiffer. (The olenid shale of Sweden.) - Sver. Geol. Unders. Ca 18, $1 \rightarrow 205$.

Боровко Н., Сергеева С. 1985. Конодонты верхнекембрийских отложений БалтийскоЛадожского глинта. - Изв. АН ЭССР. Геол., 34, 4, 125-129.

Волкова Н. А. 1982. О возрасте юлгазеской пачки на границе кембрия и ордовика в Эстонии. - Сов. геол., 9, 85-88.

Волкова Н. А. 1989. Акритархи пограничных отложений кембрия и ордовика севера Эстонии. - Изв. АН СССР. Сер. геол., 7, 59-67.

Волкова Н. А. 1990. Акритархи среднего и верхнего кембрия Восточно-Европейской платформы. Наука, Москва.

Волкова Н. А., Голуб И. Н. 1985. Новые акритархи верхнего кембрия Ленинградской области (ладожская свита). - Палеонтол. ж., 4, 90-98.

Волқова Н., Каяк К., Менс Қ., Пиррус Э. 1981. Новыс данные о переходных слоях между кембрием и ордовиком на востоке Прибалтики. - Изв. АН ЭССР. Геол., 30, 2, 51-55.

Попов Л. Е., Хазанович К. К. 1989. Лингулаты (беззамковые брахиоподы с фосфатнокальциевой раковиной). - In: Опорные разрезы и стратиграфия кемброордовикской фосфоритоносной оболовой толщй на северо-западе Русской платформы. Наука, Ленинград, 96-136.

Попов Л. Е., Сергеева С. П., Хазанович К. К. 1989. Биостратиграфическое расчленение. - In: Опорные разрезы и стратиграфия кембро-ордовикской фосфоритоносной оболовой толщи на северо-западе Русской платформы. Наука, Ленинград, 85-95.

Хейнсалу Х., Вийра В., Менс К., Оя Т., Пуура И. 1987. Кембрийско-ордовикские пограничные отложения разреза Юлгазе, Северная Эстония. - Изв. АН ЭССР. Геол., 36, 4, 154-165.

Хейнсалу Х., Вийра В., Паалитс И. 1991. Пограничные кембро-ордовикские отложения разреза Сака II в Северо-Восточной Эстонии. - Изв. АН Эстонии. Геол., 40, 1, 8-15.

\section{ULEMKAMBRIUMI BIOSTRATIGRAAFIA EESTIS}

\section{Kaisa MENS, Viive VIIRA, Ivo PAALITS, Ivar PUURA}

Ulemkambriumi läbilõigete kivimilise koostise ja ehituse järgi kuulub Eesti fatsiaalsesse üleminekuvööndisse.

Olemkambriumi biostratigraafiliseks liigestamiseks analüüsiti akritarhide, konodontide ja lingulaatide levikut mitmetes paljandites ning puursüdamikes. Saadud andmete põhjal on esitatud Eesti ülemkambriumi biotsonaalne liigestus, bioüksuste omavahelised suhted, samuti ka korrelatsioon trilobiitide tsoonidega.

\section{БИОСТРАТИГРАФИЯ ВЕРХНЕГО КЕМБРИЯ ЭСТОНИИ}

\section{Кайса МЕНС, Вийве ВИН̈РА, Иво ПААЛИТС, Ивар ПУУРА}

На основе анализа вертикального распределения акритарх, конодонтов и лингулат выделены сообщества этих фоссилий и по ним расчленен разрез верхнего кембрия Әстонии на биостратиграфические подразделения. По результатам сравнения родового и видового составов этих сообществ с соответствующими материалами из разрезов, охарактеризованных трилобитами, выделенные биостратиграфические подразделения сопоставлены с трилобитовой зональной шкалой платформы (таблица). 